\title{
Diet Supplementation with Fish Oil and Sunflower Oil to Increase Conjugated Linoleic Acid Levels in Milk Fat of Partially Grazing Dairy Cows
}

\author{
A. A. AbuGhazaleh and L. D. Holmes \\ Department of Animal Science, Food and Nutrition, Southern Illinois University, Carbondale 62901
}

\begin{abstract}
The objective of this study was to determine the longterm effect on milk conjugated linoleic acid (cis-9, trans11 CLA) of adding fish oil (FO) and sunflower oil (SFO) to the diets of partially grazing dairy cows. Fourteen Holstein cows were divided into 2 groups ( 7 cows/treatment) and fed either a control or oil-supplemented diet for 8 wk while partially grazing pasture. Cows in group 1 were fed a grain mix diet $(8.0 \mathrm{~kg} / \mathrm{d}, \mathrm{DM}$ basis) containing $400 \mathrm{~g}$ of saturated animal fat (control). Cows in the second group were fed the same grain mix diet except the saturated animal fat was replaced with 100 $\mathrm{g}$ of FO and $300 \mathrm{~g}$ of SFO. Cows were milked twice a day and milk samples were collected weekly throughout the trial. Both groups grazed together on alfalfa-based pasture ad libitum and were fed their treatment diets after the morning and afternoon milking. Milk production ( 30.0 and $31.2 \mathrm{~kg} / \mathrm{d}$ ), milk fat percentages (3.64 and 3.50 ), milk fat yield (1.08 and $1.09 \mathrm{~kg} / \mathrm{d}$ ), milk protein percentages (2.97 and 2.88), and milk protein yield ( 0.99 and $0.91 \mathrm{~kg} / \mathrm{d}$ ) for diets 1 and 2 , respectively, were not affected by the treatment diets. The concentrations of cis-9, trans-11 CLA (1.64 vs. $0.84 \mathrm{~g} / 100 \mathrm{~g}$ of fatty acids) and vaccenic acid (5.11 vs. $2.20 \mathrm{~g} / 100 \mathrm{~g}$ of fatty acids) in milk fat were higher for cows fed the oil-supplemented diet over the $8 \mathrm{wk}$ of oil supplementation. The concentration of cis-9, trans-11 CLA in milk fat reached a maximum ( 1.0 and $1.64 \mathrm{~g} / 100 \mathrm{~g}$ of fatty acids for diets 1 and 2, respectively) in wk 1 for both diets and remained relatively constant thereafter. The concentration of vaccenic acid in milk fat followed the same temporal pattern as cis-9, trans-11 CLA. In conclusion, supplementing the diet of partially grazing cows with FO and SFO increased the milk cis-9, trans-11 CLA content, and that increase remained relatively constant after 1 wk of oil supplementation.
\end{abstract}

Received October 18, 2006.

Accepted January 22, 2007.

${ }^{1}$ Corresponding author: aabugha@siu.edu
Key words: grazing, fish oil, sunflower oil, conjugated linoleic acid

\section{INTRODUCTION}

Conjugated linoleic acid (CLA) is a collective term for geometric and positional isomers of linoleic acid. The primary CLA isomer in dairy products, cis-9, trans11 CLA, is a potential anticarcinogen in animal models (Ip et al., 1999). Cis-9, trans-11 CLA is an intermediate in the ruminal biohydrogenation of linoleic acid and is thought to be the primary source of cis-9, trans-11 CLA in milk fat. Recently, however, research has shown that endogenous synthesis of cis-9, trans-11 CLA also occurs. Trans-11 18:1 (vaccenic acid, VA), an intermediate in the biohydrogenation of both linoleic and linolenic acids while in the tissues, can be acted on by the $\Delta^{9}$-desaturase enzyme, causing its conversion into cis-9, trans- 11 CLA. Recent studies (Corl et al., 2001; Kay et al., 2004) have estimated that more than $90 \%$ of milk cis-9, trans11 CLA is made by the activity of the $\Delta^{9}$-desaturase enzyme.

Cows fed pasture-based diets have been shown to have consistently more CLA in their milk than cows fed TMR diets (Kelly et al., 1998; Dhiman et al., 1999; Khanal et al., 2005; Couvreur et al., 2006). Dhiman et al. (1999) assigned cows to 3 treatment groups to consume either one-third, two-thirds, or all of their daily feed from pasture. The CLA concentrations in the milk for the 3 groups were 8.9, 14.3, and $22.1 \mathrm{mg} / \mathrm{g}$ of milk fatty acids in the one-third, two-thirds, and allpasture treatments, respectively. Recently, Couvreur et al. (2006) reported a linear relationship between the proportion of fresh grass in dairy cow diets and milk cis-9, trans-11 CLA.

Milk cis-9, trans-11 CLA content has also been shown to be affected by dietary oil supplementations. Feeding fish oil (FO) or oils high in linoleic or linolenic acid has been shown to be an effective way to enhance the cis9, trans-11 level in milk. The milk cis-9, trans-11 CLA concentration increased by $360 \%$ when FO was fed at $2 \%$ of dietary DM (Donovan et al., 2000). When fed $2 \%$ 
oil from extruded soybeans, milk cis-9, trans-11 CLA and VA concentrations increased by 200 and $230 \%$, respectively (Whitlock et al., 2002). AbuGhazaleh et al. (2002) observed that supplementing the diet of lactating cows with a blend of fish meal and extruded soybeans was more efficient in enhancing the milk contents of VA and cis-9, trans-11 CLA than when these supplements were fed separately. Later, AbuGhazaleh et al. (2003b) concluded that supplementing the diet of dairy cows with a combination of $\mathrm{FO}$ and a high-linoleic oil source was the most efficient dietary regimen to increase milk cis-9, trans-11 CLA.

The effect of oil supplementation on milk cis-9, trans11 CLA concentration over time has not been consistent. Previous studies have indicated that a plateau is reached within $1 \mathrm{wk}$ (Shingfield et al., 2006), $2 \mathrm{wk}$ (Whitlock et al., 2002), or 3 wk (AbuGhazaleh et al., 2004) of dietary oil supplementation. The objective of the present study was to evaluate the effect of supplementing the diet of partially grazing dairy cows with a blend of FO and sunflower oil (SFO) for an extended period of time on milk cis-9, trans-11 CLA.

\section{MATERIALS AND METHODS}

Fourteen multiparous Holstein cows were used in a grazing study from April through June 2005. Cows were selected from the herd of the Southern Illinois University Dairy Cattle Research Center (Carbondale, IL). Two weeks before the start of the study, all cows were fed the control grain mix (control, $8 \mathrm{~kg} / \mathrm{d}$ ) and offered free access to a corn silage and alfalfa hay mix (50:50). Milk production was recorded daily and milk samples were taken from each cow during the last $2 \mathrm{~d}$ (0600 and $1800 \mathrm{~h}$ ) of wk 1 and 2 for composition and fatty acid analyses. Milk production and composition data generated during these $2 \mathrm{wk}$ were used for covariance analysis. At the end of the 2-wk adjustment period, cows were paired on the basis of milk yield $(32 \pm 4 \mathrm{~kg} / \mathrm{d})$ and DIM (108 \pm 18$)$, and were assigned to 2 treatments using a complete randomized design. Treatments were 1) pasture supplemented with $8 \mathrm{~kg} / \mathrm{d}$ of grain mix containing $400 \mathrm{~g}$ of saturated animal fat (control); and 2) pasture supplemented with $8 \mathrm{~kg} / \mathrm{d}$ of grain mix containing $100 \mathrm{~g}$ of FO and $300 \mathrm{~g}$ of SFO (FOSFO; Table 1). Grain mixes were formulated to be isocaloric and isonitrogenous (Table 1). Menhaden FO (Omega Protein Inc., Hammond, LA) and Rumo-fat (Robt Morgan Inc., Paris, IL), a source of saturated animal fat, were used in this study. All cows were grazed together for 8 wk under intensive rotational grazing management. The pasture consisted of alfalfa, fescue, and weeds (70:20:10 wt/wt). The pasture area was a 8.4 -ha area and was divided into fourteen 0.6 -ha paddocks. All cows were moved to a new paddock every day. Energized polywire fencing prevented cows from grazing the next day's allotment and from grazing previously grazed areas. Cows had free access to water and commercial saltbased mineral blocks. Grain mix was offered in 2 equal feedings after the morning and afternoon milkings in the barn using Calan Broadbent feeder doors (American Calan Inc., Northwood, NH) for individual feed intakes. The amounts of grain mix offered and orts were recorded daily for individual cows. Cows remained on the pasture daily for about $21 \mathrm{~h}$.

Cows were milked daily at 0600 and $1800 \mathrm{~h}$ during the trial. Milk yield was recorded at each milking. Milk samples were collected at 4 consecutive milkings (p.m. and a.m.) on the last $2 \mathrm{~d}$ of each week throughout the 8 -wk trial. Twenty-four-hour composites of each cow's milk, amounts proportional to milk yield at each time, were divided into 2 portions for analysis. One portion was refrigerated at $4^{\circ} \mathrm{C}$ and sent to a laboratory to be analyzed for fat, protein, lactose, and solids (AOAC, 1997) by midinfrared spectrophotometry (Prairie Farms, Carlinville, IL); SCC (AOAC, 1997) were determined using a Fossomatic 90 instrument (Prairie Farms). The other portion of each sample was stored at $-20^{\circ} \mathrm{C}$ until analysis for fatty acid composition.

On the last day of each week, samples of grain mix and pasture were collected for composition analyses. Representative pasture samples were collected from 6 different locations per 0.6 -ha paddock grazed by cows using a $0.50-\mathrm{m}^{2}$ quadrant. The plants were clipped to a $2.5-\mathrm{cm}$ stubble height using metal shears. Pasture samples were composited per week and stored at $-20^{\circ} \mathrm{C}$ until analysis for chemical and fatty acid composition.

Grain mix and pasture samples were freeze-dried (Labconco Freeze Dry System, Labconco, Kansas City, MO) and then ground through a standard model No. 3 Wiley mill (Arthur H. Thomas Co., Philadelphia, PA) with a $2-\mathrm{mm}$ screen. Samples were analyzed for CP, ether extract, and ash according to AOAC methods (1997). Samples were reground (Brinkman ultracentrifuge mill, Brinkman Instruments, Westbury, NY) through a 1-mm screen prior to analyzing fatty acids (Kramer et al., 1997) and fiber. Neutral detergent fiber (procedure B of Van Soest et al., 1991) and ADF (Robertson and Van Soest, 1981) were determined by an Ankom fiber analyzer using the filter bag technique (Ankom Technology Corp., Fairport, NY). Body weights and BCS (Wildman et al., 1982) were recorded at the beginning and end of the trial.

Milk samples were thawed in a $35^{\circ} \mathrm{C}$ water bath and $1 \mathrm{~mL}$ was transferred into glass test tubes $(16 \times 200$ $\mathrm{mm}$ ) with Teflon-lined screw caps, stored at $-80^{\circ} \mathrm{C}$ for $6 \mathrm{~h}$, freeze-dried, and then methylated using the 2-step procedure outlined by Kramer et al. (1997). Methylated 
Table 1. Ingredient and nutrient content of experimental diets and pasture

\begin{tabular}{|c|c|c|c|}
\hline \multirow[b]{2}{*}{ Item } & \multicolumn{2}{|c|}{$\operatorname{Diet}^{1}$} & \multirow[b]{2}{*}{ Pasture $^{2}$} \\
\hline & Control & FOSFO & \\
\hline \multicolumn{4}{|l|}{ Ingredient, \% of DM } \\
\hline Cracked corn & 51.88 & 51.88 & \\
\hline Soybean meal, $48 \% \mathrm{CP}$ & 30.63 & 30.63 & \\
\hline Molasses & 6.25 & 6.25 & \\
\hline Rumo-fat ${ }^{3}$ & 5.00 & 0.00 & \\
\hline Fish oil & 0.00 & 1.25 & \\
\hline Sunflower oil & 0.00 & 3.75 & \\
\hline Limestone & 3.13 & 3.13 & \\
\hline Dicalcium phosphate & 1.56 & 1.56 & \\
\hline Magnesium oxide & 0.31 & 0.31 & \\
\hline $\mathrm{Zn}$ trace mineralized salt & 0.63 & 0.63 & \\
\hline Vitamin E premix & 0.31 & 0.31 & \\
\hline Vitamin A, D, E premix & 0.31 & 0.31 & \\
\hline \multicolumn{4}{|c|}{ Chemical composition, g/kg of DM } \\
\hline CP & $21.31 \pm 1.54$ & $23.08 \pm 1.38$ & $17.93 \pm 2.48$ \\
\hline Ether extract & $9.12 \pm 0.37$ & $8.51 \pm 0.20$ & $3.72 \pm 0.26$ \\
\hline $\mathrm{ADF}$ & $10.26 \pm 0.61$ & $8.41 \pm 0.29$ & $31.8 \pm 1.77$ \\
\hline $\mathrm{NDF}$ & $19.64 \pm 0.81$ & $14.98 \pm 1.21$ & $48.83 \pm 2.06$ \\
\hline Ash & $8.73 \pm 1.02$ & $9.76 \pm 0.91$ & $6.22 \pm 0.73$ \\
\hline
\end{tabular}

fatty acids were then analyzed for fatty acids using a Shimadzu GC-2010 gas chromatograph (Shimadzu Scientific Instruments, Inc., Columbia, MD) equipped with a flame-ionization detector and a Supelco 100-m SP-2560 fused-silica capillary column $(0.25 \mathrm{~mm}$ i.d. $\times$ $0.2 \mu \mathrm{m}$ film thickness). The helium carrier gas was maintained at a linear velocity of $23 \mathrm{~cm} / \mathrm{s}$. The oven temperature was programmed for $170^{\circ} \mathrm{C}$ for $50 \mathrm{~min}$, then increased at $5^{\circ} \mathrm{C} / \mathrm{min}$ to $249^{\circ} \mathrm{C}$ and held for 10 $\mathrm{min}$. The injector and detector temperatures were set at $255^{\circ} \mathrm{C}$. Peaks were identified by comparing the retention times with those of the corresponding standards (Nu-Chek Prep, Elysian, MN; Supelco, Bellefonte, PA; and Larodan Fine Chemicals, Malmo, Sweden).

Analysis of variance was conducted using the Mixed procedure (SAS Institute, 1996) for a completely randomized design with repeated measures. Data from the adjustment period (2-wk pretreatment) were used for covariance analysis for all variables. The model contained the effects of covariance, diet, week, and diet $\times$ week interaction. Cow within diet was used as an error term. Least squares means are reported throughout, and significance was declared at $P<0.05$ unless otherwise noted.

\section{RESULTS AND DISCUSSION}

The chemical and fatty acid composition of the grain mixes and pasture are presented in Tables 1 and 2 . Grain mix CP, ADF, NDF, ether extract, and ash were similar for both diets, averaging 22.2, 9.33, 17.31, 8.81, and $8.8 \%$, respectively. The average $\mathrm{CP}, \mathrm{ADF}, \mathrm{NDF}$, ether extract, and ash for pasture were 17.93, 31.8, $48.8,3.72$, and $6.22 \%$, respectively. Grain mixes varied in their fatty acid profile. In the control diet, stearic acid was the major fatty acid, accounting for $54 \%$ of total fatty acids, whereas oleic and linoleic acids accounted only for 8 and $14 \%$ of total fatty acids, respectively. Stearic acid was the major fatty acid in the Rumo-fat supplement (63\%; Table 2). Oleic and linoleic acids were the major fatty acids in the FOSFO diet, accounting for 36.6 and $34.5 \%$ of total fatty acids, respectively. The unexpectedly high oleic acid concentration found in the FOSFO diet was due to high oleic levels from the sunflower oil. Typically, linoleic acid levels account for $70 \%$ of total fatty acids in SFO (Casper et al., 1988), as compared with the $29 \%$ present in our SFO supplement (Table 2). Linolenic acid was the primary fatty acid in pasture, averaging $38.5 \%$ of total fatty acids.

Inclusion of FO and SFO in the diet had no effect ( $P$ $>0.05$ ) on milk yield, milk composition, and grain intake (Table 3). Milk yield and grain intake averaged 30.6 and $7.6 \mathrm{~kg} / \mathrm{d}$, respectively over the 8 -wk trial. Rego et al. (2005b) also reported no differences in milk yield between grazing dairy cows fed $5 \mathrm{~kg}$ of concentrate or $4.5 \mathrm{~kg}$ of concentrate plus $500 \mathrm{~g}$ of SFO. However, milk yield decreased when $320 \mathrm{~g}$ of FO was added to the diet of the grazing dairy cow, compared with the control (Rego et al., 2005a). Supplementing diets with oils rich 
Table 2. Fatty acid composition for treatment diets, pasture, and oil supplements

\begin{tabular}{|c|c|c|c|c|c|c|}
\hline \multirow{2}{*}{$\begin{array}{l}\text { Fatty } \\
\text { acid }\end{array}$} & \multicolumn{2}{|c|}{$\operatorname{Diet}^{1}$} & \multirow[b]{2}{*}{ Pasture $^{2}$} & \multirow{2}{*}{$\begin{array}{c}\text { Sunflower } \\
\text { oil }\end{array}$} & \multirow{2}{*}{$\begin{array}{l}\text { Fish } \\
\text { oil }\end{array}$} & \multirow[b]{2}{*}{ Rumo-fat ${ }^{3}$} \\
\hline & Control & FOSFO & & & & \\
\hline & & & - $(\mathrm{g} / 100$ & ty acids) & & 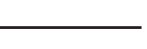 \\
\hline $14: 0$ & 1.53 & 0.92 & 0.37 & 0.07 & 6.79 & 2.86 \\
\hline $14: 1$ & $\mathrm{ND}^{4}$ & ND & 9.27 & ND & ND & ND \\
\hline $16: 0$ & 16.19 & 9.41 & 11.96 & 4.55 & 16.67 & 25.26 \\
\hline 18:0 & 53.74 & 5.44 & 1.59 & 3.54 & 3.41 & 63.46 \\
\hline $18: 1$ & 8.03 & 36.63 & 2.54 & 59.04 & 9.22 & 0.35 \\
\hline $18: 2$ & 13.96 & 34.48 & 12.26 & 28.98 & 1.13 & 0.04 \\
\hline 18:3 & 0.76 & 1.46 & 38.49 & 0.41 & 1.49 & ND \\
\hline $20: 5$ & 0.09 & 1.05 & 0.04 & 0.03 & 10.72 & ND \\
\hline $22: 6$ & 0.10 & 1.27 & 0.10 & 0.04 & 13.15 & ND \\
\hline
\end{tabular}

d.

${ }^{2}$ Control $=400 \mathrm{~g} / \mathrm{d}$ of saturated animal fat (Rumo-fat); FOSFO $=100 \mathrm{~g}$ of fish oil $+300 \mathrm{~g}$ of sunflower oil/

${ }^{2}$ Pasture $=70: 20: 10$ alfalfa:fescue:weeds

${ }^{3}$ Rumo-fat (Robt Morgan Inc., Paris, IL).

${ }^{4} \mathrm{ND}=$ Not detected or detected at $P<0.01$.

in polyunsaturated fatty acids often results in a reduction in feed intake and therefore milk yield (Chilliard et al., 2001; Lock and Shingfield, 2004). The equal intake of grain mixes in this experiment and the low concentration of polyunsaturated fatty acids in the FOSFO may explain the similar milk yield for the 2 diets. Milk yield remained relatively constant for the first $4 \mathrm{wk}$, averaging $32.6 \mathrm{~kg}$, and then steadily declined with both diets to approximately $28.6 \mathrm{~kg}$ (Figure 1). Higher average ambient temperature during the months of May $\left(17.7^{\circ} \mathrm{C}\right)$ and June $\left(24.6^{\circ} \mathrm{C}\right)$ compared with April $\left(13.8^{\circ} \mathrm{C}\right)$ may explain, in part, the drop in milk yield.

The fat content and yield were similar for both diets (Table 3), averaging $3.64 \%$ and $1.08 \mathrm{~kg} / \mathrm{d}$, respectively, for the control diet and $3.50 \%$ and $1.09 \mathrm{~kg} / \mathrm{d}$ for the FOSFO diet. Past studies have reported that inclusion of FO, SFO, or both in the dairy cow diet consistently decreased milk fat content and yield under confinement (Donovan et al., 2000; AbuGhazaleh et al., 2003b) or pasture (Rego et al., 2005a,b) management systems. Previously, AbuGhazaleh et al. (2003b) reported a drop in milk fat content for cows fed high-oleic and regular sunflower seeds. It is unclear why the milk fat content was not decreased with the FOSFO diet in this study. One possible explanation might be an increase in NEFA uptake by the mammary gland as a result of body fat mobilization. By the end of the trial, the cows on pasture had lost about 0.5 units of BCS. Similar drops in BCS for cows on pasture have been reported by others

Table 3. Mean effect of treatment diets on milk yield, composition, and grain mix intake during the 8-wk trial

\begin{tabular}{|c|c|c|c|c|c|}
\hline \multirow[b]{2}{*}{ Item } & \multicolumn{2}{|c|}{$\operatorname{Diet}^{1}$} & \multirow[b]{2}{*}{ SEM } & \multicolumn{2}{|c|}{$P$-value } \\
\hline & Control & FOSFO & & Diet & Diet $\times$ week $^{2}$ \\
\hline Milk, kg/d & 30.03 & 31.23 & 0.83 & 0.33 & 0.75 \\
\hline \multicolumn{6}{|l|}{ Fat } \\
\hline$\%$ & 3.64 & 3.50 & 0.10 & 0.33 & 0.10 \\
\hline $\mathrm{kg} / \mathrm{d}$ & 1.08 & 1.09 & 0.02 & 0.77 & 0.51 \\
\hline \multicolumn{6}{|l|}{ Protein } \\
\hline$\%$ & 2.97 & 2.88 & 0.06 & 0.31 & 0.23 \\
\hline $\mathrm{kg} / \mathrm{d}$ & 0.99 & 0.91 & 0.03 & 0.63 & 0.96 \\
\hline Lactose, \% & 4.69 & 4.77 & 0.04 & 0.16 & 0.02 \\
\hline Total solids, \% & 12.22 & 12.16 & 0.14 & 0.77 & 0.17 \\
\hline $\mathrm{SCC}, \times 10^{3} / \mathrm{mL}$ & 209.91 & 85.18 & 28.90 & 0.01 & 0.12 \\
\hline Grain mix intake, kg/d & 7.60 & 7.60 & 0.14 & 0.90 & 0.24 \\
\hline $\mathrm{BCS}^{3}$ & 2.70 & 2.60 & 0.25 & 0.65 & 0.81 \\
\hline $\mathrm{BW}, \mathrm{kg}$ & 581 & 575 & 11.60 & 0.45 & 0.14 \\
\hline
\end{tabular}

${ }^{1}$ Control $=400 \mathrm{~g} / \mathrm{d}$ of saturated animal fat (Rumo-fat, Robt Morgan Inc., Paris, IL); FOSFO = $100 \mathrm{~g}$ of fish oil $+300 \mathrm{~g}$ of sunflower oil/d.

${ }^{2}$ Diet $\times$ week interaction effect.

${ }^{3}$ Scored on a 5 -point scale, where 1 = emaciated to 5 = overly fat (Wildman et al., 1982). 


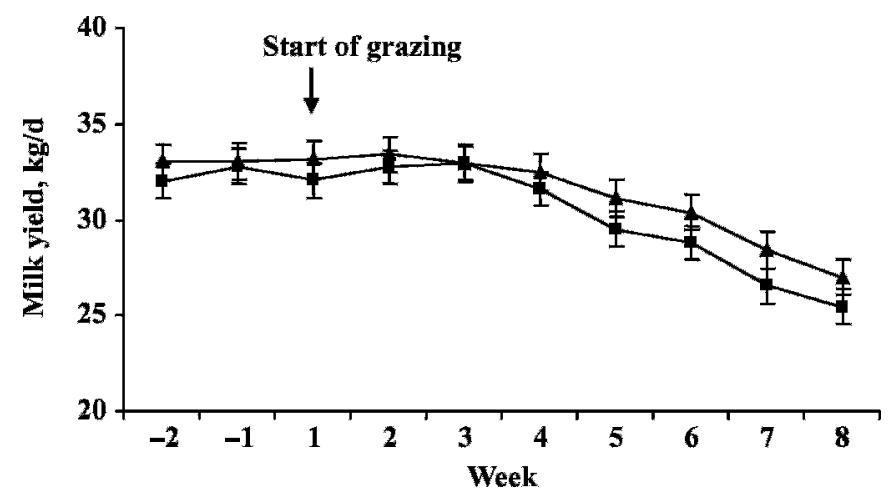

Figure 1. Changes in milk yield with time for pasture cows on control ( $\mathbf{\square})$ or $100 \mathrm{~g}$ of fish oil $+300 \mathrm{~g}$ of sunflower oil ( $\mathbf{\Delta})$ diets. Standard errors of the mean averaged 0.94.

(Schroeder et al., 2003; Boken et al., 2005). This explanation is further supported by the increase in milk fat content seen in this study starting on wk 4 (Figure 2).

Milk protein content and yield were similar $(P=0.31)$ for both treatments, averaging $2.92 \%$ and $0.95 \mathrm{~kg} / \mathrm{d}$, respectively. Supplementing the diet of the grazing cow with $500 \mathrm{~g}$ of SFO or soybean oil did not affect the milk protein content or yield (Rego et al., 2005b). Similarly, Kitessa et al. (2004) reported no difference in the milk protein content in cows on pasture fed a diet with or without tuna oil. In the present study, treatment diets had no effect $(P>0.05)$ on milk lactose and total solids; however, SCC was lower $(P<0.05)$ with the FOSFO diet compared with the control diet (Table 3). Cows began the trial with a mean BCS of 3.2 and at the end of the 8-wk grazing trial, the mean BCS was 2.65 , with a similar change in BCS units from each diet.

The effect of treatment diets on the concentrations of $\mathrm{C}_{6}$ to $\mathrm{C}_{16}$ fatty acids in milk fat is presented in Table

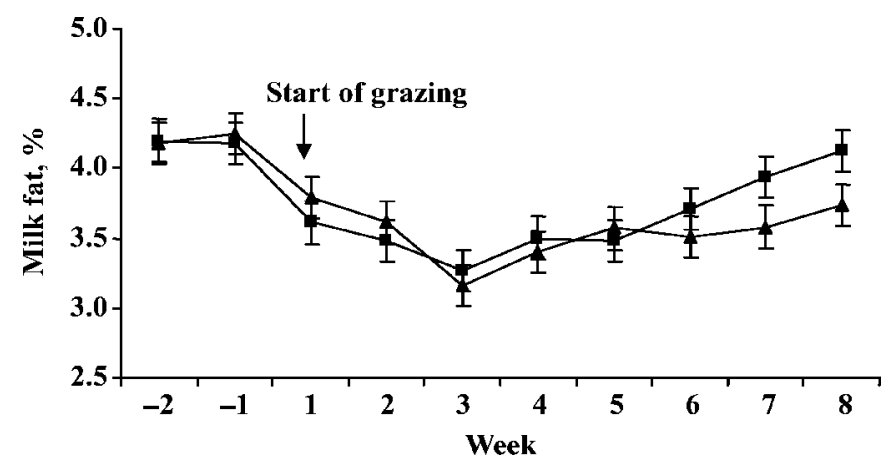

Figure 2. Changes in milk fat percentages with time for pasture

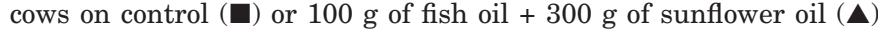
diets. Standard errors of the mean averaged 0.15.
4. Compared with the control diet, the inclusion of FO and SFO in the diet resulted in decreases $(P<0.05)$ in the concentrations of milk $\mathrm{C}_{6}$ to $\mathrm{C}_{16}$ fatty acids ( $42.5 \mathrm{vs}$. $33.9 \%$ of total fatty acids; Table 4). Feeding unsaturated oils is typically associated with a decrease in the de novo synthesis of short- and medium-chain fatty acids (Mohamed et al., 1988; Kim et al., 1993; AbuGhazaleh et al., 2002; Rego et al., 2005b). The decrease in medium-chain fatty acids may represent an improvement in the profile of milk fatty acids, because these fatty acids have been reported to constitute the hypercholesterolemic portion of milk fat (Ney, 1991). Except for $\mathrm{C}_{15}$ and $\mathrm{C}_{17}$, the diet $\times$ week interaction was not significant for $\mathrm{C}_{4}$ to $\mathrm{C}_{17}$ fatty acids. Concentrations of stearic, oleic, and linolenic acids in milk fat were similar with both diets.

The main objective of this study was to evaluate the effects on milk cis-9, trans-11 CLA of feeding a CLAstimulating diet to partially grazing dairy cows for an extended period of time. We are not aware of published studies that have evaluated the long-term effects on milk cis-9, trans-11 CLA of supplementing the diet of partially grazing dairy cows with a blend of FO and SFO. The concentration of milk cis-9, trans-11 CLA during the 8 -wk trial was higher $(P<0.05)$ for cows fed the FOSFO diet compared with cows fed the control diet, averaging 1.64 and $0.84 \mathrm{~g} / 100 \mathrm{~g}$ of fatty acids, respectively (Table 4). Supplementing the diets of grazing dairy cows with $500 \mathrm{~g} / \mathrm{d}$ of SFO or soybean oil resulted in 68 and 53\% increases in milk CLA compared with control cows (Rego et al., 2005b). Lawless et al. (1998) reported a 28 and $43 \%$ increase in milk CLA when pasture-grazed cows were fed full-fat soybeans or full-fat rapeseeds, respectively. Compared with pasture-grazed cows on the control diet, supplementing the diet of grazing dairy cows with 160 and $320 \mathrm{~g}$ of $\mathrm{FO} / \mathrm{d}$ resulted in 44 and $62 \%$ increases, respectively, in milk CLA concentrations (Rego et al., 2005a). In the present study, the diet $\times$ week interaction was significant $(P$ $<0.05$ ) for milk cis-9, trans-11 CLA (Figure 3). The concentration of cis-9, trans-11 CLA in milk fat increased to 0.98 and $1.67 \mathrm{~g} / 100 \mathrm{~g}$ of fatty acids by the end of the first week of grazing for the control and FOSFO diets, respectively, and remained relatively constant throughout the remainder of the trial period (Figure 3). The effect of oil supplementation on milk cis-9, trans-11 CLA concentrations over time has not been consistent. Concentrations of cis-9, trans-11 CLA in milk fat from diets containing fish meal and extruded soybeans have been reported to increase until d 21 on the diet then decline thereafter (AbuGhazaleh et al., 2004). In a 12 -wk study, the milk cis-9, trans-11 CLA concentration continued to increase until wk 8 , and then declined thereafter when cows were grazed and 
Table 4. Mean effect of treatment diets on milk fatty acid composition

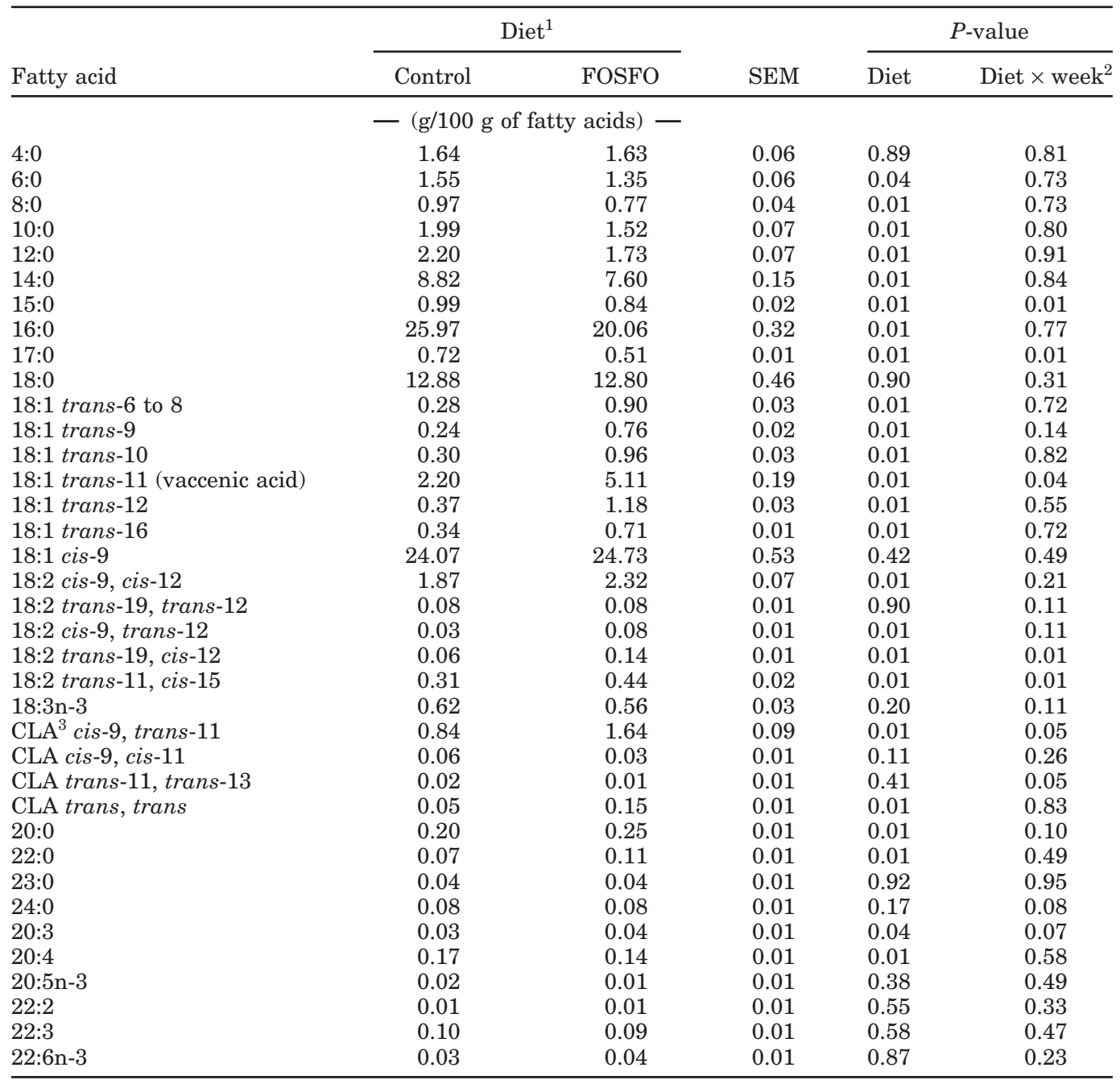

${ }^{1}$ Control $=400 \mathrm{~g} / \mathrm{d}$ of saturated animal fat (Rumo-fat, Robt Morgan Inc., Paris, IL); FOSFO = $100 \mathrm{~g}$ of fish oil $+300 \mathrm{~g}$ of sunflower oil/d.

${ }^{2}$ Diet $\times$ week interaction effect.

${ }^{3} \mathrm{CLA}=$ conjugated linoleic acid.

fed mechanically extracted soybean meal (Loor et al., 2002). In a more recent study (Shingfield et al., 2006), cis-9, trans-11 CLA in milk fat reached its highest concentration by $\mathrm{d} 5$, then declined thereafter when dairy cow diets were supplemented with a blend of FO and SFO. In a 3-wk study, Bauman et al. (2000) also reported a greater cis-9, trans-11 CLA concentration in milk during the first week of SFO supplementation.

The effects of treatment diets on the concentrations of milk trans 18:1 isomers, VA in particular, are presented in Table 4. Because part of the VA in the human body can be converted into cis-9, trans-11 CLA (Salminen et al., 1998), producing milk with a high VA concentration could be also beneficial. The inclusion of $\mathrm{FO}$ and SFO in the diet resulted in a higher $(P<0.05)$ milk VA concentration (5.11 g/100 g of fatty acids) compared with the control diet ( $2.20 \mathrm{~g} / 100 \mathrm{~g}$ of fatty acids). Similar increases in milk VA concentrations were observed previously (AbuGhazaleh et al., 2003a,b) when cows were fed a blend of FO and SFO under a confinement management system. The low increase in milk VA concentration with the FOSFO diet in this study (132\%), compared with the 321 and $250 \%$ increase reported by AbuGhazaleh et al. (2002) and Whitlock et al. (2002), respectively, when cows were fed a blend of FO and extruded soybeans (linoleic acid source), may be explained by the lower amounts of oil supplement used in this study ( $400 \mathrm{~g} / \mathrm{d}$ vs. 560 and $675 \mathrm{~g} / \mathrm{d}$ ) or the high oleic acid content in our SFO (Table 2) or both. Linoleic acid has been shown to be more efficient than oleic 


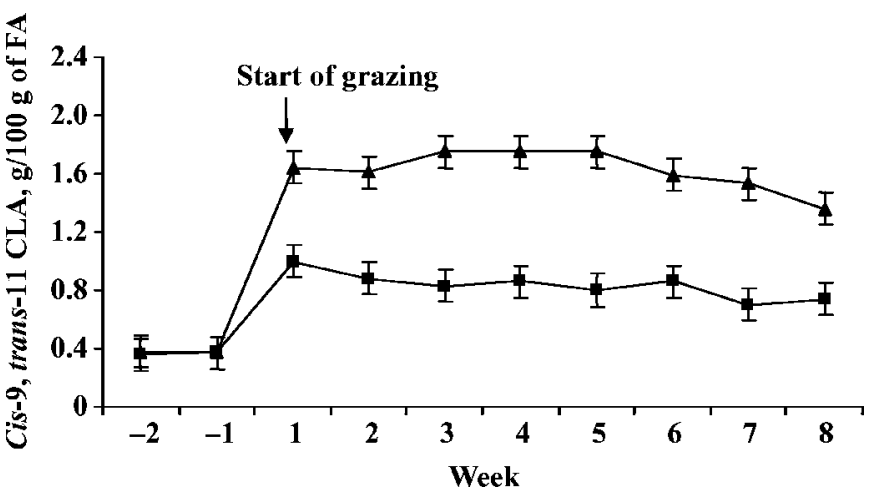

Figure 3. Changes in milk cis-9, trans-11 conjugated linoleic acid (CLA) with time for pasture cows on control (ם) or $100 \mathrm{~g}$ of fish oil $+300 \mathrm{~g}$ of sunflower oil ( $\mathbf{\Delta})$ diets. Standard errors of the mean averaged $0.11 . \mathrm{FA}=$ fatty acids.

acid in promoting higher VA concentrations in the milk (AbuGhazaleh et al., 2003b) and rumen (AbuGhazaleh et al., 2003a, 2005). Similar to milk cis-9, trans-11 CLA, the diet $\times$ week interaction was significant $(P<0.05)$ for milk VA (Figure 4). The concentration of VA in milk fat reached a maximum by the end of the first week of grazing (2.38 and $5.38 \mathrm{~g} / 100 \mathrm{~g}$ of fatty acids for the control and FOSFO diets, respectively) and remained relatively constant throughout the reminder of the trial period. Previously, AbuGhazaleh et al. (2004) observed a gradual increase in milk VA concentration until d 21, when cows were fed a TMR diet containing fish meal and extruded soybeans. When cows were grazed and fed mechanically extracted soybean meal for $12 \mathrm{wk}$, the milk VA concentration continued to increase until wk 8 , and then declined thereafter (Loor et al., 2002). When Shingfield et al. (2006) supplemented the dairy cow diet with a blend of FO and SFO, milk VA reached its highest concentration by $\mathrm{d} 5$, then declined thereafter. Abu-

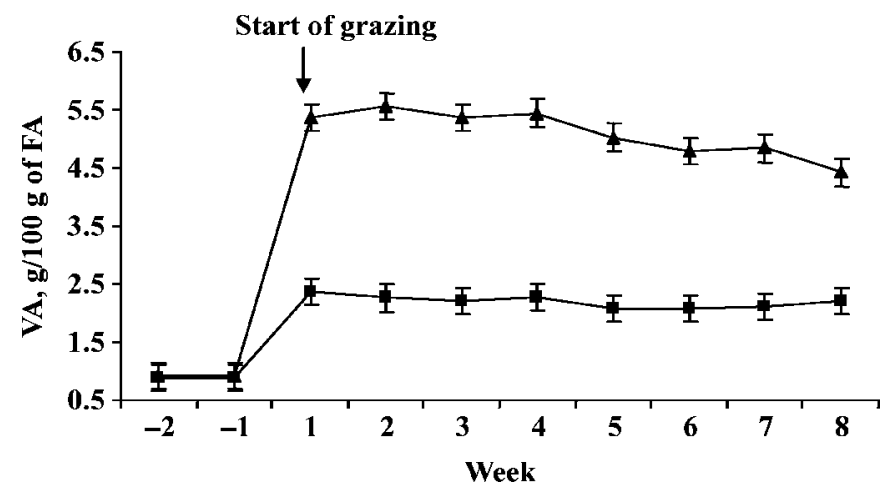

Figure 4. Changes in milk vaccenic acid (VA) with time for pasture cows on control ( $\mathbf{\square})$ or $100 \mathrm{~g}$ of fish oil $+300 \mathrm{~g}$ of sunflower oil (A) diets. Standard errors of the mean averaged 0.23 . FA = fatty acids.

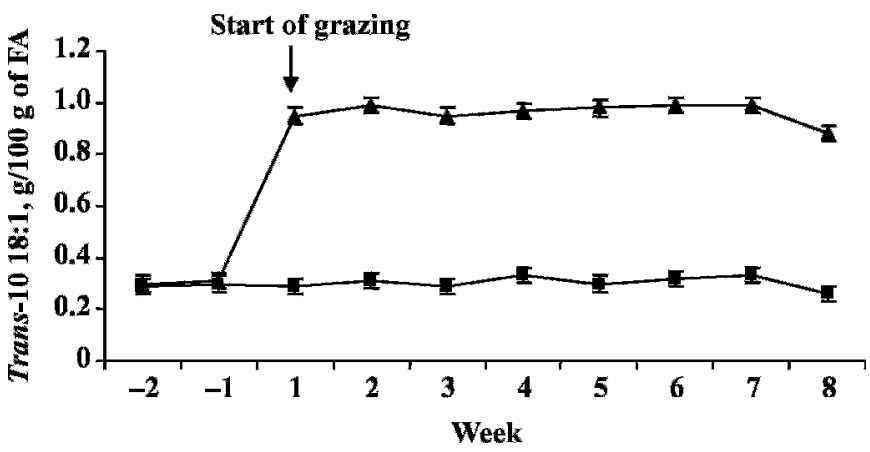

Figure 5. Changes in milk trans-10 18:1 with time for pasture cows on control (ם) or $100 \mathrm{~g}$ of fish oil $+300 \mathrm{~g}$ of sunflower oil (A) diets. Standard errors of the mean averaged 0.03 . FA = fatty acids.

Ghazaleh et al. (2004) suggested that the transitory pattern of changes in the milk VA concentration may arise from time-dependent adaptations in ruminal microbial populations, enzymatic activities, or both. Recently, Shingfield et al. (2006) reported that the decline in VA concentration in milk fat by d 5 was associated with a concomitant increase in several trans 18:1 isomers, particularly trans-10 18:1. In the current study, by the end of the first week of grazing, the trans-10 18:1 concentration in milk fat had increased from 0.30 to $0.90 \%$ for the FOSFO diet and remained relatively constant throughout the remainder of the trial period (Figure 5). The trans-10 18:1 concentration in milk fat did not change throughout the trial period in cows fed the control diet, and the concentration was similar to that in the pretrial (Figure 5). What seems evident from this study and others (Loor et al., 2002, AbuGhazaleh et al., 2004, Shingfield et al., 2006) is that the transitory pattern in milk VA and cis-9, trans-11 CLA is influenced by oil and forage sources. Further research is needed to address the effect of forage and oil sources and amounts on the transitory pattern of changes in milk cis-9, trans-11 CLA and VA.

\section{CONCLUSIONS}

Inclusion of FO and SFO in the diet of partially grazing dairy cows had no effect on milk yield and composition. Milk cis-9, trans-11 CLA and VA concentrations increased with FO and SFO supplementation compared with the control diet, and the increase reached a maximum by the end of wk 1 and remained relatively constant throughout the remainder of the 8-wk study.

\section{REFERENCES}

AbuGhazaleh, A. A., G. Apgar, B. Jacoboson. 2005. The effect of docosahexaenoic acid on the production of vaccenic acid and conjugated linoleic acid from unsaturated $\mathrm{C}_{18}$ fatty acids in rumen cultures. J. Dairy Sci (Suppl. 1)88:180. (Abstr.) 
AbuGhazaleh A. A., D. J. Schingoethe, A. R. Hippen, and K. F. Kalscheur. 2003a. Conjugated linoleic acid and vaccenic acid in rumen, plasma, and milk of cows fed fish oil and fats differing in saturation of 18 carbon fatty acids. J. Dairy Sci. 86:3648-3660.

AbuGhazaleh, A. A., D. J. Schingoethe, A. R. Hippen, K. F. Kalscheur. 2004. Conjugated linoleic acid increases in milk when cows fed fish meal and extruded soybeans for an extended period of time. J. Dairy Sci. 87:1758-1766.

AbuGhazaleh, A. A., D. J. Schingoethe, A. R. Hippen, K. F. Kalscheur. 2003b. Milk conjugated linoleic acid response to fish oil supplementation diets differing in fatty acid profiles. J. Dairy Sci. 86:944-953.

AbuGhazaleh, A. A., D. J. Schingoethe, A. R. Hippen, and L. A. Whitlock. 2002. Feeding fish meal and extruded soybeans enhances the conjugated linoleic acid content of milk. J. Dairy Sci. 85:624-631.

AOAC. 1997. Official Methods of Analysis. 16th ed. AOAC Intl., Gaithersburg, MD.

Bauman, D. E., D. M. Barbano, D. A. Dwyer, and J. M. Griinari. 2000. Technical note: Production of butter with enhanced conjugated linoleic acid for use in biomedical studies with animal models. J. Dairy Sci. 83:2422-2425.

Boken, S. L., C. R. Staples, L. E. Sollenberger, T. C. Jenkins, and W. W. Thatcher. 2005. Effect of grazing and fat supplementation on production and reproduction of Holstein cows. J. Dairy Sci. 88:4258-4272.

Casper, D. P., D. J. Schingoethe, R. P. Middaugh, and R. J. Baer. 1988. Lactational responses of dairy cows to diets containing regular and high oleic sunflower seeds. J. Dairy Sci. 71:12671274.

Chilliard, Y., A. Ferlay, and M. Doreau. 2001. Effect of different types of forages, animal fat or marine oils in cow's diet on milk fat secretion and composition, especially conjugated linoleic acid (CLA) and polyunsaturated fatty acids. Livest. Prod. Sci. 70:31-48.

Corl, B. A., L. H. Baumgard, D. A. Dwyer, J. M. Griinari, B. S. Phillips, and D. E. Bauman. 2001. The role of $\Delta^{9}$-desaturase in the production of cis-9, trans-11 CLA. J. Nutr. Biochem. 12:622-630.

Couvreur, S., C. Hurtaud, C. Lopez, L. Delaby, and J. L. Peyraud. 2006. The linear relationship between the proportion of fresh grass in the cow diet, milk fatty acid composition, and butter properties. J. Dairy Sci. 89:1956-1969.

Dhiman, T. R., G. R. Anand, L. D. Satter, and M. W. Pariza. 1999. Conjugated linoleic acid content of milk from cows fed different diets. J. Dairy Sci. 82:2146-2156.

Donovan, D. C., D. J. Schingoethe, R. J. Baer, J. Ryali, A. R. Hippen, and S. T. Franklin. 2000. Influence of dietary fish oil on conjugated linoleic acid and other fatty acids in milk fat from lactating dairy cows. J. Dairy Sci. 83:2620-2628.

Kay, J. K., T. R. Mackle, M. J. Auldist, N. A. Thomson, and D. E. Bauman. 2004. Endogenous synthesis of cis-9, trans-11 CLA in dairy cows fed fresh pasture. J. Dairy Sci. 87:369-378.

Kelly, M. L., E. S. Kolver, D. E. Bauman, M. E. Van Amburgh, and L. D. Muller. 1998. Effect of intake of pasture on concentrations of conjugated linoleic acid in milk of lactation cows. J. Anim. Sci. 81:1630-1636.

Khanal, R. C., T. R. Dhiman, A. L. Ure, C. P. Brennand, R. L. Boman, and D. J. McMahon. 2005. Consumer acceptability of conjugated linoleic acid-enriched milk and Cheddar cheese from cows grazing on pasture. J. Dairy Sci. 88:1837-1847.

Kim, Y. K., D. J. Schingoethe, D. P. Casper, and F. C. Ludens. 1993. 1993. Supplemental dietary fat from extruded soybeans and calcium soaps of fatty acids for lactating dairy cows. J. Dairy Sci. $76: 197-204$

Kitessa, S. M., S. K. Gulati, G. C. Simos, J. R. Ashes, T. W. Scott, E. Fleck, and P. C. Wynn. 2004. Supplementation of grazing dairy cows with rumen-protected tuna oil enriches milk fat with n-3 fatty acids without affecting milk production or sensory characteristics. Br. J. Nutr. 91:271-277.

Kramer, J. K., V. Feller, M. E. Dugan, F. D. Sauer, M. M. Mossoba, and M. P. Yurawecz. 1997. Evaluating acid and base catalysts in the methylation of milk and rumen fatty acids with special emphasis on conjugated dienes and total trans fatty acids. Lipids $32: 1219-1228$.

Lawless, F., J. J. Murphy, D. Harrington, R. Devery, and C. Stanton. 1998. Elevation of conjugated cis-9, trans-11-octadecadienoic acid in bovine milk because of dietary supplementation. J. Dairy Sci. 81:3259-3267.

Lock, A. L., and K. J. Shingfield. 2004. Optimizing milk composition. Pages 107-188 in Dairying-Using Science to Meet Consumers Needs. Br. Soc. Anim. Sci. Publ. 29. E. Kebreab, J. Mills, and D. E. Beever, ed. Nottingham University Press, Loughborough, UK.

Loor, J. J., J. H. Herbein, and C. E. Polan. 2002. Trans 18:1 and 18:2 isomers in blood plasma and milk fat of grazing cows fed a grain supplement containing solvent-extracted or mechanically extracted soybean meal. J. Dairy Sci. 85:1197-1207.

Mohamed, O. E., L. D. Satter, R. R. Grummer, and F. R. Ehle. 1988. Influence of dietary cottonseed and soybean on milk production and composition. J. Dairy Sci. 71:2677-2688.

Ney, D. M. 1991. Potential for enhancing the nutritional properties of milk fat. J. Dairy Sci. 74:4002-4012.

Ip, C., S. Banni, E. Angioni, G. Carta, J. McGinley, H. J. Thompson, D. Barbano, and D. Bauman. 1999. Conjugated linoleic acid-enriched butter fat alters mammary gland morphogenesis and reduces cancer risk in rats. J. Nutr. 129:2135-2142.

Rego, O. A., H. J. D. Rosa, P. V. Portugal, R. Corderio, A. E. S. Borba, C. M. Vouzela, and R. J. B. Bessa. 2005a. Influence of dietary fish on conjugated linoleic acid, omega-3 and other fatty acids in milk fat from grazing dairy cows. Livest. Prod. Sci. 95:27-33.

Rego, O. A., H. J. D. Rosa, P. V. Portugal, T. Franco, C. M. Vouzela, A. E. S. Borba, and R. J. B. Bessa. 2005b. The effects of supplementation with sunflower and soybean oils on the fatty acid profile of milk fat from grazing dairy cows. Anim. Res. 54:17-24.

Robertson, J. B., and P. J. Van Soest. 1981. The detergent system of analysis and its application to human foods. Pages 123-129 in the Analysis of Dietary Fiber. W. P. T. James and O. Theander, ed. Marcel Dekker, New York, NY.

Salminen, I., M. Mutanen, M. Jauhiainen, and A. Aro. 1998. Dietary trans fatty acids increase conjugated linoleic acid levels in human serum. J. Nutr. Biochem. 9:93-98.

SAS Institute. 1996. SAS/STAT: Changes and Enhancements Through Release 6.11. SAS Inst. Inc., Cary, NC.

Schroeder, G. F., J. E. Delahoy, I. Vidaurreta, F. Bargo, G. A. Gagliostro, and L. D. Muller. 2003. Milk fatty acid composition of cows fed a total mixed ration or pasture plus concentrates replacing corn with fat. J. Dairy Sci. 86:3237-3248.

Shingfield, K. J., C. K. Reynolds, G. Hervas, J. M. Griinari, A. S Grandison, and D. E. Beever. 2006. Examination of the persistency of milk fatty acid composition responses to fish oil and sunflower oil in the diet of dairy cows. J. Dairy Sci. 89:714-732.

Van Soest, P. J., J. B. Robertson, and B. A. Lewis. 1991. Methods for dietary fiber, neutral detergent fiber, and non-starch polysaccharides in relation to animal nutrition. J. Dairy Sci. 74:35833597.

Wildman, E. E., G. M. Jones, P. E. Wagner, R. L. Bowman, H. F. Troutt, and T. N. Lesch. 1982. Dairy cow body condition scoring and its relationship to selected production characteristics. J. Dairy Sci. 65:495-501.

Whitlock, L., D. J. Schingoethe, A. R. Hippen, K. F. Kalscheur, R. J. Baer, N. Ramaswamy, and K. M. Kasperson. 2002. Fish oil and extruded soybeans fed in combination increase CLA in milk of dairy cows more than when fed separately. J. Dairy Sci. 85:234-243. 